\title{
Phosphoglycerates and Protein Phosphorylation: Identification of a Protein Substrate as Glucose-1,6-Bisphosphate Synthetase
}

\author{
${ }^{*}$ Hideo Morino, ${ }^{*}$ Carolyn Fischer-Bovenkerk, ${ }^{*}$ Phillip E. Kish, and ${ }^{*} \uparrow$ Tetsufumi Ueda \\ ${ }^{*}$ Mental Health Research Institute and $\dagger$ Departments of Pharmacology and Psychiatry, \\ University of Michigan, Ann Arbor, Michigan, U.S.A.
}

\begin{abstract}
We have previously reported the occurrence of two endogenous protein phosphorylation systems in mammalian brain that are enhanced in the presence of 3-phosphoglycerate (3PG) and ATP. We present here a study of one of these systems, the phosphorylation of the $72-\mathrm{kDa}$ protein (3PG$\mathrm{PP}_{72}$ ). This system was separated into the substrate, 3PG$\mathrm{PP}_{72}$, and a kinase by ammonium sulfate fractionation, hydroxyapatite chromatography, and hydrophobic interaction HPLC. The substrate protein was shown to be directly phosphorylated with $\left[1-{ }^{32} \mathrm{P}\right] 1,3$-bisphosphoglycerate ([1$\left.{ }^{32} \mathrm{P}\right] 1,3 \mathrm{BPG}$ ) with an apparent $K_{\mathrm{m}}$ of $1.1 \mathrm{n} M$. Nonradioactive $1,3 \mathrm{BPG}$ inhibited ${ }^{32} \mathrm{P}$ incorporation in the presence of $[\gamma-$ ${ }^{32}$ P]ATP and 3PG. Phosphopeptide mapping and phosphoamino acid analyses indicated that the site of phosphorylation of 3 PG-PP $P_{72}$ observed in the presence of $3 P G$ and ATP is a serine residue identical to that observed with $\left[1-{ }^{32} \mathrm{P}\right] 1,3 \mathrm{BPG}$.
\end{abstract}

Moreover, $\left[{ }^{32} \mathrm{P}\right]$ phosphate incorporated into $3 \mathrm{PG}-\mathrm{PP}_{72}$ in the presence of $3 P$ G and ATP was removed by subsequent incubation with glucose-1-phosphate or glucose-6-phosphate. Finally, $3 \mathrm{PG}-\mathrm{PP}_{72}$ showed chromatographic behaviors identical to those of glucose-1,6-bisphosphate $\left(\mathrm{Gl}, 6 \mathrm{P}_{2}\right)$ synthetase. Based upon these observations, we conclude that $3 \mathrm{PG}-\mathrm{PP}_{72}$ is $\mathrm{Gl}, 6 \mathrm{P}_{2}$ synthetase and that it is phosphorylated directly by $1,3 \mathrm{BPG}$, which is formed from $3 \mathrm{PG}$ and ATP by $3 \mathrm{PG}$ kinase present in a crude $3 \mathrm{PG}_{-} \mathrm{PP}_{72}$ preparation. Key Words: Protein phosphorylation-3-Phosphoglycerate-Phosphoprotein-Glucose-1,6-bisphosphate synthetase-1,3-Bisphosphoglycerate-Brain. Morino H. et al. Phosphoglycerates and protein phosphorylation: Identification of a protein substrate as glucose-1,6-bisphosphate synthetase. J. Neurochem. 56, 1049-1057 (1991).
Glucose metabolism is of vital importance for brain function. Although glucose is the major substrate for energy production in the brain under normal conditions (Siesjö, 1978), it is now apparent that ATP alone is not sufficient to maintain synaptic function (Dirks et al., 1980; Winkler, 1981; Cox and Bachelard, 1982; Ghajar et al., 1982). This information raised the possibility that glycolysis or a glycolytic intermediate, in addition to ATP, might play a role in synaptic transmission in normal physiological states. In view of these considerations, together with the growing evidence for the role of protein phosphorylation in the function of the nervous system (Nestler and Greengard, 1984), a search was made for a potential link between glycolysis and protein phosphorylation (Ueda and Plagens, 1987). It was found that 3-phosphoglycerate (3PG), one of the glycolytic intermediates, stimulates the phosphorylation of two specific proteins in the brain with molecular weights of 72,000 and 155,000, referred to as 3PG-' $P_{72}$ and $3 P G-P P_{155}$. Toward an understanding of the nature of one of the phosphoproteins, $3 \mathrm{PG}-\mathrm{PP}_{72}$, we have carried out its purification in this study.

During the course of purifying $3 \mathrm{PG}-\mathrm{PP}_{72}$, we noted that its molecular weight in sodium dodecyl sulfate (SDS) was similar to that of glucose-1,6-bisphosphate $\left(\mathrm{G} 1,6 \mathrm{P}_{2}\right)$ synthetase, which is phosphorylated by 1,3 bisphosphoglycerate (1,3BPG) (Rose et al., 1975). $\mathrm{G} 1,6 \mathrm{P}_{2}$ synthetase was found to be present at high concentrations in the brain (Rose et al., 1975, 1977), as is the case for $3 P G-P_{72}$ (Ueda and Plagens, 1987). In addition, the reported ammonium sulfate fractionation and hydroxyapatite chromatographic behavior of
Received August 3, 1990; accepted September 18, 1990.

Address correspondence and reprint requests to Dr. T. Ueda at Mental Health Research Institute, University of Michigan, 205 Washtenaw Pl., Ann Arbor, MI 48109, U.S.A.

The present address of Dr. H. Morino is Department of Neuropsychiatry, Ehime University School of Medicine, Shizukawa, Shi- genobu-cho, Onsen-gan, Ehime 791-02, Japan.

Abbreviations used: 1,3BPG, 1,3-bisphosphoglycerate; GI,6 $\mathbf{P}_{2}$, glucose-1,6-bisphosphate; PAGE, polyacrylamide gel electrophoresis; 3PG, 3-phosphoglycerate; 3PG-PP 72 , 72-kDa protein phosphorylated in presence of 3PG; 3PG-PP $155,155-\mathrm{kDa}$ protein phosphorylated in presence of 3PG; SDS, sodium dodecyl sulfate. 
G1,6P 2 synthetase (Wong and Rose, 1976) appeared similar to that of $3 P G-P_{72}$. These observations raised the possibility that $3 \mathrm{PG}-\mathrm{PP}_{72}$ might be phosphorylated directly by $1,3 \mathrm{BPG}$, which could have been formed from 3PG and ATP catalyzed by an endogenous source of enzyme, which could be 3PG kinase (ATP:3-phospho-D-glycerate 1-phosphotransferase, EC 2.7.2.3), and that $3 \mathrm{PG}-\mathrm{PP}_{72}$ might be $\mathrm{G1}, 6 \mathrm{P}_{2}$ synthetase. Hence, we set out to determine the identity of $3 \mathrm{PG}^{-\mathrm{PP}_{72}}$ as $\mathrm{G} 1,6 \mathrm{P}_{2}$ synthetase. The potential role of $\mathrm{Gl}, 6 \mathrm{P}_{2}$ synthetase in synaptic function is discussed. We have also determined whether 3 PG-PP ${ }_{155}$ is phosphorylated directly by $1,3 \mathrm{BPG}$.

\section{MATERIALS AND METHODS}

\section{Materials}

$\left[\gamma^{-32} \mathrm{P}\right] \mathrm{ATP}(7,000 \mathrm{Ci} / \mathrm{mmol}),\left[{ }^{32} \mathrm{P}\right] \mathrm{P}_{\mathrm{i}}(285 \mathrm{Ci} / \mathrm{mg})$, and gel electrophoresis reagents were obtained from ICN Biomedicals. Spherogel TSK Phenyl 5PW and Ultrasil SAX columns were purchased from Beckman Instruments. Biogel HTP (hydroxyapatite), Econo-Pak 10DG, and molecular weight standards were from Bio-Rad Laboratories. Glycolytic intermediates and all other chemicals were obtained from Sigma.

\section{Protein phosphorylation assay}

The phosphorylation assay was carried out as described by Ueda and Plagens (1987). The standard incubation mixture contained, in a final volume of $100 \mu \mathrm{l}, 5 \mu \mathrm{mol}$ of Tris- $\mathrm{HCl}$ $(\mathrm{pH} 7.4), 1 \mu \mathrm{mol}$ of $\mathrm{MgSO}_{4}, 0.5 \mu \mathrm{mol} 3 \mathrm{PG}, 2 \mathrm{nmol}$ of $[\gamma-$ $\left.{ }^{32} \mathrm{P}\right] \mathrm{ATP}(16.5 \mathrm{Ci} / \mathrm{mmol})$, and appropriate amounts of synaptosomal cytosol or other samples after various steps of purification. When fractions were assayed for the presence of substrate, a small amount of exogenous microsomal kinase (preparation described below) was added. When 3PG-PP was phosphorylated by $\left[1-{ }^{32} \mathrm{P}\right] 1,3 \mathrm{BPG}$, the incubation mixture contained, in a final volume of $100 \mu 1,5 \mu \mathrm{mol}$ of Tris$\mathrm{HCl}(\mathrm{pH} 7.4), 1 \mu \mathrm{mol}$ of $\mathrm{MgSO}_{4}, 1 \mathrm{nmol}$ of [1- $\left.{ }^{32} \mathrm{P}\right] 1.3 \mathrm{BPG}$ $(10.6 \mathrm{Ci} / \mathrm{mol})$, and an appropriate amount of the fraction containing 3PG-PP 72 . Slab SDS-polyacrylamide gel electrophoresis (PAGE) and autoradiography were carried out as described by Ueda and Greengard (1977), and the amounts of $\left[{ }^{32} \mathrm{P}\right]$ phosphate incorporated into $3 \mathrm{PG}-\mathrm{PP}_{72}$ were estimated by the densitometric method as described in Ueda et al. (1973) or determined directly by excising and measuring the radioactivity of the portion of the gel corresponding to 3 PG-PP ${ }_{72}$.

\section{Preparation of microsomal source of kinase}

A kinase that phosphorylates specific proteins in the presence of $3 P G$ and ATP has been found in a particulate fraction rich in microsomes from rat brain (Ueda and Plagens, 1987). Fresh rat cerebrum was homogenized in 10 vols of $0.32 \mathrm{M}$ sucrose and subjected to differential centrifugation to obtain the microsomal pellet. The pellet, obtained after centrifuging at $150,000 \mathrm{~g}_{\max }$ for $60 \mathrm{~min}$, was resuspended in 10 vols of $0.32 M$ sucrose. The kinase was extracted from the microsome suspension with $0.2 \%$ Triton $\mathrm{X}-100$ on ice for $30 \mathrm{~min}$. The mixture was then centrifuged at $150,000 \mathrm{~g}_{\max }$ for $60 \mathrm{~min}$ and the clear supernatant was stored at $-20^{\circ} \mathrm{C}$ and used as an exogenous source of 3PG-dependent kinase.

\section{Preparation of synaptosomal cytosol}

Fresh bovine brains were obtained from a local slaughterhouse, transported on ice, and processed immediately. The synaptosmal cytosol fraction was prepared as described pre- viously (Ueda et al., 1979). Bovine cerebral cortex was homogenized in an isotonic $0.32 M$ sucrose solution and the synaptosomal (pinched-off nerve endings) fraction was prepared by successive differential and sucrose density gradient centrifugations. The synaptosome-rich fraction was lysed at pH 8.1 (6 m $M$ Tris-maleate) and centrifuged at $36,000 g_{\max }$ for $20 \mathrm{~min}$. The resulting supernatant was centrifuged at $150,000 g_{\max }$ for $60 \mathrm{~min}$ to pellet synaptic vesicles and small plasma membrane fragments. The supernatant (synaptosomal cytosol fraction) was frozen at $-20^{\circ} \mathrm{C}$.

\section{Separation of 1,3BPG from ATP and $P_{i}$}

A Beckman Ultrasil SAX column $(250 \times 4.6 \mathrm{~mm})$ HPLC system was used for the separation of 1,3BPG, ATP, and $P_{i}$ and a wavelength of $214 \mathrm{~nm}$ was selected to monitor the eluate from the column. The column was equilibrated with $0.4 M$ potassium phosphate buffer ( $\mathrm{pH} 3.2$ ) for $>1 \mathrm{~h}$ at a flow rate of $1.0 \mathrm{ml} / \mathrm{min}$. Samples were applied in $100 \mu \mathrm{l}$ and eluted with the same buffer at a flow rate of $1.0 \mathrm{ml} / \mathrm{min}$ and eluates were collected in $1-\mathrm{ml}$ fractions. 1,3BPG showed a retention time of $12.6 \mathrm{~min}$. Retention times for the other related compounds were $3.5 \mathrm{~min}$ for $\mathrm{P}_{\mathrm{i}}$ and glyceraldehyde3-phosphate, $3.7 \mathrm{~min}$ for pyruvate, $4.9 \mathrm{~min}$ for $3 \mathrm{PG}, 21.9$ min for 2,3-bisphosphoglycerate, and $22.5 \mathrm{~min}$ for ATP. The $1,3 \mathrm{BPG}$ peak fraction was identified using both radioactive and nonradioactive 1,3BPG, which had each been synthesized enzymatically. The nonradioactive $1,3 \mathrm{BPG}$, which was dissolved in $10 \mathrm{~m} M$ glycylglycine buffer ( $\mathrm{pH} 7.5$ ) containing $0.2 \mathrm{M} \mathrm{NaCl}$, showed one major peak (retention time, 12.6 $\mathrm{min}$ ) and two minor peaks (retention times, 3.5 and $4.9 \mathrm{~min}$ ) of absorbance at $214 \mathrm{~nm}$, in addition to the peak corresponding to glycylglycine (retention time, $3.2 \mathrm{~min}$ ). The radioactive sample exhibited a major peak of radioactivity with retention time of $12.6 \mathrm{~min}$. When this radioactive substance was treated with acid-molybdate in the presence of isobutanol/benzene, the radioactivity was recovered in the organic phase, which suggested the release of ${ }^{32} \mathrm{P}_{\mathrm{i}}$ under acid conditions (Wong and Rose, 1976). These observations indicated that the substance in the major peak fraction was $1,3 \mathrm{BPG}$, and therefore it was used as 1,3BPG.

\section{Synthesis of $\left[1{ }^{32} \mathrm{P}\right] 1,3 \mathrm{BPG}$}

$\left[1-{ }^{32} \mathrm{P}\right] 1,3 \mathrm{BPG}$ and nonradioactive $1,3 \mathrm{BPG}$ were synthesized according to an enzymatic method of Rose (1968) except that the enzymes were removed at the end of synthesis by the use of an Amicon Centriprep-10 concentrator. Radioactivity that amounted to $90 \%$ of the original ${ }^{32} P_{i}$ radioactivity was recovered. The specific activity and purity of [1$\left.{ }^{32} \mathrm{P}\right] 1,3 \mathrm{BPG}$ were determined using an HPLC system. Sixtyeight percent of the total radioactivity of the $\left[1-{ }^{32} \mathrm{P}\right] 1,3 \mathrm{BPG}$ preparation was associated with $\left[1{ }^{32} \mathrm{P}\right] 1,3 \mathrm{BPG}$, while $8.0 \%$ was with $P_{i}$. The specific activity was $10.6 \mathrm{Ci} / \mathrm{mmol}$ and the yield was $61.2 \%$. The specific activity was lower than that of $P_{\mathrm{i}}$ added to the incubation mixture $(40.3 \mathrm{Ci} / \mathrm{mmol})$. This was due to the decomposition of some of the glyceraldehyde-3phosphate to $\mathrm{P}_{\mathrm{i}}$ and glyceraldehyde; thus, the resulting specific activity of $P_{j}$ was decreased in the incubation mixture. It was calculated that the decomposition of $1.33 \%$ of glyceraldehyde3-phosphate per $25 \mathrm{~min}$ at $25^{\circ} \mathrm{C}$ (data supplied from Sigma) could lead to the decreased specific activity of $P_{i}$ in the incubation mixture. Nonradioactive 1,3BPG was determined according to Negelein et al. (1957) and used as the standard for the determination of the radioactive 1,3BPG by HPLC. The yield of the nonradioactive preparation was $32.8 \%$ and it contained $\sim 12 \% 3 \mathrm{PG}$ and $\mathrm{P}_{\mathrm{i}}$. 
Assay for $\mathrm{G1}_{1,6 \mathrm{P}_{2}}$ synthetase and 3PG kinase

G1,6 $\mathbf{P}_{2}$ synthetase was assayed according to Wong and Rose (1976). Activity of 3PG kinase was measured according to Scopes (1975).

Peptide mapping and phosphoamino acid analysis of 3PG-PP 72

The 3 PG-PP ${ }_{72}$ fraction from hydroxyapatite chromatography or a mixture of the $3 \mathrm{PG}-\mathrm{PP}_{72}$ fraction and a kinase fraction from HPLC on the Phenyl SPW column was incubated with either $\left[\gamma{ }^{32} \mathrm{P}\right] A T P$ or $\left[1-{ }^{32} \mathrm{P}\right] 1,3 \mathrm{BPG}$. Phosphorylated samples $(250 \mu \mathrm{l})$ were subjected to SDS-PAGE. Limited proteolytic digestion and two-dimensional mapping were performed as described by Stratford et al. (1984) and Huttner and Greengard (1979). Tryptic and chymotryptic digests were also subjected to phosphoamino acid analysis according to Stratford et al. (1984).

\section{Protein determination}

Protein concentration was determined by the method of Lowry et al. (1951), with bovine serum albumin as standard. The amount of 3 PG-PP ${ }_{72}$ in the 3 PG-PP ${ }_{72}$ fraction from the two chromatographies was determined by densitometric tracing of the Coomassie Blue-stained protein band that corresponded to the band of $3 \mathrm{PG}-\mathrm{PP}_{72}$ on autoradiogram. Bovine serum albumin was used as a standard.

\section{RESULTS}

Separation of 3PG-PP ${ }_{72}$ and endogenous kinase

Preparation of fraction $B$. The synaptosomal cytosol isolated from six bovine brains was thawed and then fractionated with ammonium sulfate at $0-35 \%$ (fraction A), 35-60\% (fraction B), and 60-100\% (fraction C) saturation. Each fraction was dissolved in a small amount of $10 \mathrm{~m} M$ Tris- $\mathrm{HCl}(\mathrm{pH} \mathrm{7.4)}$. After this procedure and all subsequent purification steps, fractions were assayed for enzyme activity as described above. Fraction B contained the majority of $3 \mathrm{PG}-\mathrm{PP}_{72}$ and fraction $\mathrm{A}$ contained 3PG-PP ${ }_{155}$. Each fraction showed endogenous protein phosphorylation in the presence of $3 \mathrm{PG}$ and ATP that was not increased by addition of the exogenous source of kinase.

Hydroxyapatite column chromatography. Fraction B was dialyzed against $4 \mathrm{~L}$ of $5 \mathrm{~m} M$ sodium phosphate buffer ( $\mathrm{pH}$ 7.4) and applied to a hydroxyapatite column $(1.5 \times 30 \mathrm{~cm})$ equilibrated with the same buffer. After the column was washed with $150 \mathrm{ml}$ of $5 \mathrm{mM}$ sodium phosphate buffer ( $\mathrm{pH} 7.4)$, the elution was performed with a 600-ml linear gradient made of $300 \mathrm{ml}$ each of $5 \mathrm{~m} M$ and $150 \mathrm{~m} M$ sodium-potassium phosphate buffer ( $\mathrm{pH} \mathrm{7.4)} \mathrm{at} \mathrm{a} \mathrm{flow} \mathrm{rate} \mathrm{of} 100 \mathrm{ml} / \mathrm{h}$. Fractions of $10 \mathrm{ml}$ each were collected and aliquots $(60 \mu \mathrm{l})$ assayed for kinase and substrate. $3 \mathrm{PG}-\mathrm{PP}_{72}$ appeared as a single peak (Fig. 1, fractions 35-38); these fractions still showed significant endogenous protein phosphorylation with 3PG and ATP, although it was increased by the addition of the exogenous source of kinase.

Spherogel TSK Phenyl 5PW HPLC. The 3PG-PP ${ }_{72-}$ containing fractions were pooled and solid ammonium sulfate was added slowly to the fractions to give $80 \%$ saturation. After $1 \mathrm{~h}$ of stirring at $4^{\circ} \mathrm{C}$, the precipitate was collected by centrifugation at $120,000 g_{\max }$ for 30 $\mathrm{min}$. The resulting pellet was dissolved in $0.1 \mathrm{M}$ sodium phosphate ( $\mathrm{pH} 7.0)$ and applied to an Econo-Pak 10DG column that had been equilibrated with $0.1 \mathrm{M}$ sodium phosphate ( $\mathrm{pH} 7.0)$ containing $1 \mathrm{M}$ ammonium sulfate.

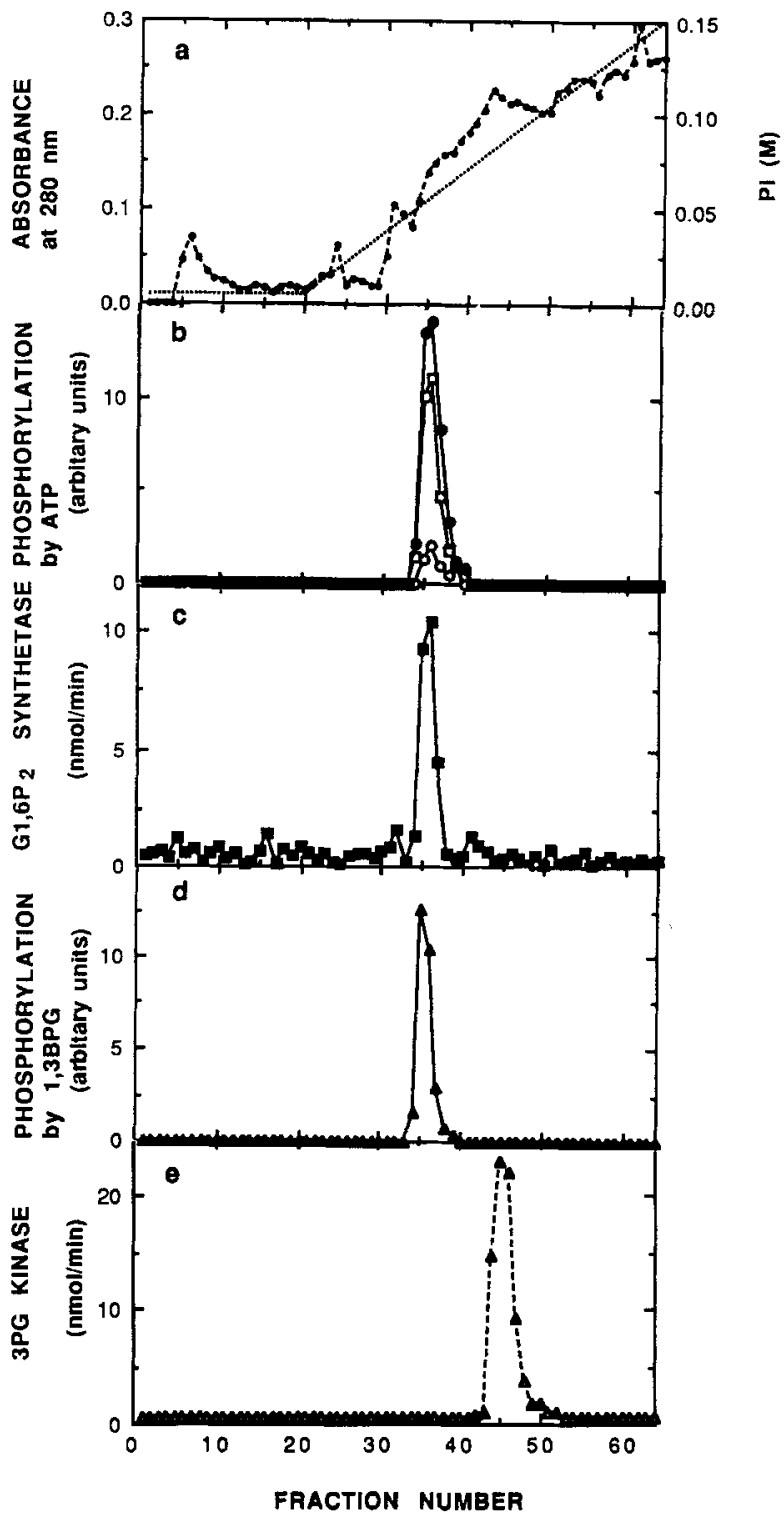

FIG. 1. Hydroxyapatite chromatography of $3 P P_{-}-P_{72}$ and $G 1,6 P_{2}$ synthetase. a: Profiles of absorbance at $280 \mathrm{~nm}$ and the gradient of phosphate concentration. b: Phosphorylation of $3 P P_{-P P}$ by ATP. An aliquot $(25 \mu l)$ of each fraction was incubated with [ $\gamma$ ${ }^{32}$ PJATP in the absence $(O)$ and presence ([]) of 3PG or in the presence of 3PG plus exogenous 3PG-dependent kinase $(4 \mu \mathrm{l} ; \bullet)$ for $5 \mathrm{~min}$. Samples were subjected to SDS-PAGE and autoradiography. ${ }^{32} \mathrm{P}$ incorporation into $3 \mathrm{PG}-\mathrm{PP}_{72}$ was estimated by the densitometric method. c: Activity of $\mathrm{G}_{1}, 6 \mathrm{P}_{2}$ synthetase. An aliquot $(50 \mu \mathrm{l})$ was used to measure the activity of $\mathrm{G}_{1}, 6 \mathrm{P}_{2}$ synthetase. $d$ : Phosphorylation of $3 P G-P P, ~ b y ~\left[1{ }^{32} P\right] 1,3 B P G$. An aliquot $(50 \mu l)$ was incubated with $\left[1{ }^{32} \mathrm{P}\right] 1,3 \mathrm{BPG}(10 \mu \mathrm{M})$ for $5 \mathrm{~min}$ and subjected to SDS-PAGE and autoradiography. ${ }^{32} P$ incorporation into $3 P G$ $\mathrm{PP}_{72}$ was estimated by the densitometric method. e: Activity of 3PG kinase. An aliquot $(400 \mu l)$ was used. 
The protein was eluted according to the instruction manual. The eluate was applied to a Spherogel TSK Phenyl 5PW column $(0.75 \times 7.5 \mathrm{~cm})$ that had been attached to a Beckman HPLC system and equilibrated with the buffer containing $1 M$ ammonium sulfate. The column was washed with $24 \mathrm{ml}$ of the same salt buffer. Then, 3PG-dependent kinase and its substrate protein were eluted from the column by decreasing the concentration of ammonium sulfate linearly from 1.0 to $0 M$ in $60 \mathrm{ml}$ of the same buffer ( $30 \mathrm{ml}$ of each) at a flow rate of $1.0 \mathrm{ml} / \mathrm{min}$. Fractions of $3 \mathrm{ml}$ each were collected. After dialysis against $5 \mathrm{~m} M$ Tris- $\mathrm{HCl}$ buffer ( $\mathrm{pH}$ 7.4), aliquots of these fractions were assayed for the presence of substrate, using the exogenous source of kinase. 3PG-PP ${ }_{72}$ appeared as a single peak (fractions 23 and 24), as shown in Fig. 2. These fractions showed only low levels of endogenous phosphorylation with 3PG and ATP, indicating a minimal contamination of kinase. When each fraction was assayed for the 3PGdependent kinase activity, using the $3 \mathrm{PG}-\mathrm{PP}_{72}$ fractions largely free of kinase as a substrate, the most prominent kinase activity was observed in fractions 28 and 29 , although multiple peaks of kinase activity were detected.

As shown in Fig. 3, the addition of fraction 28 to the substrate fraction (fraction 24) increased markedly the protein phosphorylation in the presence of $3 \mathrm{PG}$ and ATP of $3 \mathrm{PG}-\mathrm{PP}_{72}$, although each alone showed little or no detectable phosphorylation. These results support the notion that the substrate protein 3 PG-PP 72 that utilizes ATP and 3PG and a kinase exist as separate entities.

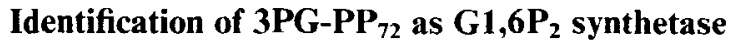

Chromatographic profile. Most of the $\mathrm{G} 1,6 \mathrm{P}_{2}$ synthetase activity was found in fraction $B$ after the ammonium sulfate fractionation, and this fraction also contained most of the 3PG-PP ${ }_{72}$. In addition, both G1,6 $P_{2}$ synthetase and $3 P G-P_{72}$ exhibited essentially identical elution profiles on hydroxyapatite and hydrophobic interaction (Phenyl 5PW) chromatography (Figs. 1 and 2). Moreover, 3PG-PP ${ }_{72}$ was labeled by $\left[1{ }^{32} \mathrm{P}\right] 1,3 \mathrm{BPG}$ (see Figs. 1, 2, 5, 7, and 9) as was $\mathrm{G1}, 6 \mathrm{P}_{2}$ synthetase. These results suggested that $3 \mathrm{PG}-\mathrm{PP}_{72}$ is $\mathrm{G} 1,6 \mathrm{P}_{2}$ synthetase.

Removal of ${ }^{32} P$ from $3 P G-P P_{72}$ by glucose-1-phosphate or glucose-6-phosphate. Since it has been shown that the phosphoryl group can be removed from the phosphoryl intermediate enzyme of $\mathrm{G} 1,6 \mathrm{P}_{2}$ synthetase by incubation with glucose-1-phosphate or glucose-6phosphate as a phosphoryl group acceptor (Rose et al., 1977), we tested a variety of glycolytic intermediates and related compounds for the ability to dephosphorylate 3 PG-PP 72 . After the fraction from hydroxyapatite chromatography was incubated with $3 P G$ and $[\gamma$ ${ }^{32}$ P]ATP for $5 \mathrm{~min}$, glucose-1-phosphate, glucose-6phosphate, $\mathrm{G} 1,6 \mathrm{P}_{2}$, fructose-1-phosphate, fructose-6phosphate, fructose-1,6-bisphosphate, fructose-2,6bisphosphate, 1,3BPG, and 2,3-bisphosphoglycerate were added, and incubation was allowed to continue

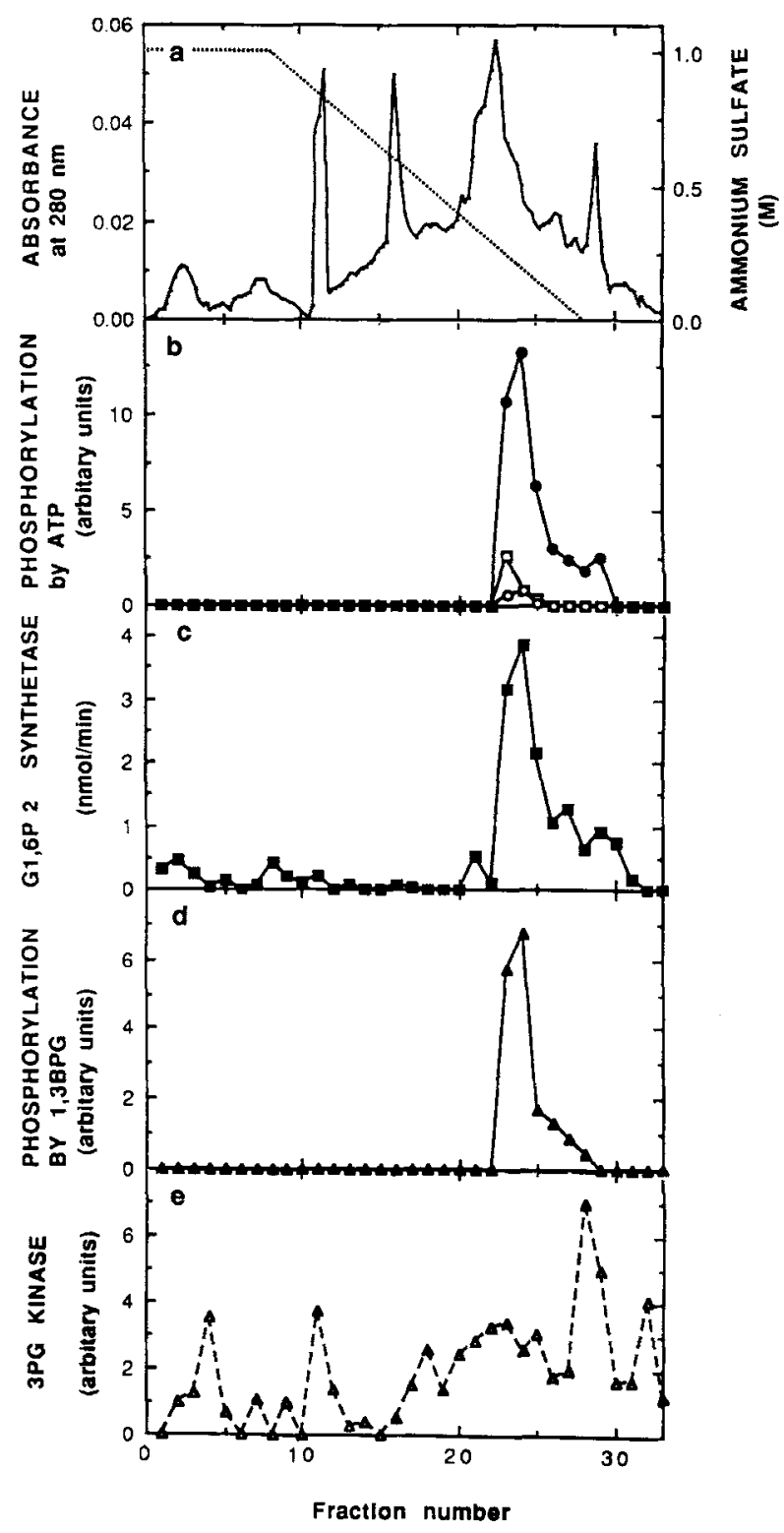

FIG. 2. Phenyl 5PW hydrophobic interaction HPLC of $3 P G-P P_{72}$ and $\mathrm{G1}, 6 \mathrm{P}_{2}$ synthetase. a: Profiles of absorbance at $280 \mathrm{~nm}$ and the change of ammonium sulfate concentration. b: Phosphorylation of 3PG-PP 72 by ATP. An aliquot of each fraction $(35 \mu l)$ was incubated with $\left[\gamma^{32} \mathrm{P}\right]$ ATP in the absence $(O)$ and presence $(\square)$ of 3PG or in the presence of 3PG plus exogenous 3PG-dependent kinase $\left(2 \mu \mathrm{l} ; 0\right.$ ) for $5 \mathrm{~min}$. ${ }^{32} \mathrm{P}$ incorporation into $3 \mathrm{PG}-\mathrm{PP}_{72}$ was estimated as described in Fig. 1. C: Activity of $\mathrm{G}_{1}, 6 \mathrm{P}_{2}$ synthetase. An aliquot $(50 \mu l)$ was used. d: Phosphorylation of 3PG-PP 72 by $\left[1{ }^{32} \mathrm{P}\right] 1,3 \mathrm{BPG}$. An aliquot $(50 \mu \mathrm{l})$ was incubated with $\left[1-{ }^{32} \mathrm{P}\right] 1,3 \mathrm{BPG}$ $\left(10{ }_{\mu} M\right){ }^{32} \mathrm{P}$ incorporation into $3 \mathrm{PG}-\mathrm{PP} \mathrm{P}_{72}$ was estimated as described in Fig. 1. e: Activity of "3PG-dependent kinase." Fractions 23 and 24 were combined and aliquots $(45 \mu l)$ were used as a substrate for "3PG-dependent kinase." Aliquots $(5 \mu \mathrm{l})$ of each fraction were added as an enzyme source to the incubation mixture, which was then incubated for $90 \mathrm{~s} .{ }^{32} \mathrm{P}$ incorporation into 3PG$P_{72}$ was detected only when both $3 P G$ and the substrate fraction were added to the incubation mixture.

for a further 2 min. As shown in Fig. 4, among the agents tested, glucose-1-phosphate caused the most marked effect on removal of ${ }^{32} \mathrm{P}$ from $\left[{ }^{32} \mathrm{P}\right] 3 \mathrm{PG}-\mathrm{PP}_{72}$, 


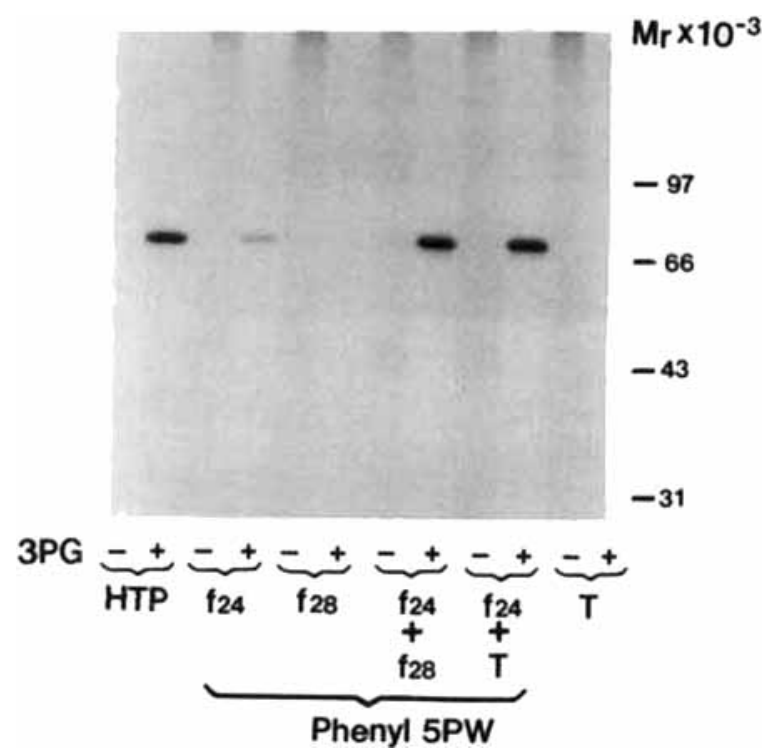

FIG. 3. Separation of $3 P G-P P_{72}$ from kinase. The $3 P G-P P_{72}$ fraction from hydroxyapatite chromatography (HTP; $7.2 \mu$ g protein), fraction 24 from Phenyl 5PW HPLC $\left(f_{24} ; 0.13 \mu \mathrm{g} 3\right.$ PG-PP 72 ), fraction 28 from Phenyl 5PW HPLC $\left(f_{28} ; 37 \mu l\right)$, fraction 24 and fraction $28\left(f_{24}\right.$ and $f_{28}$ ), fraction 24 and Triton $X-100$ extract of the rat brain microsome fraction $\left(f_{24}+T\right)$, and Triton $X-100$ extract $(T ; 2 \mu l)$ were each incubated in the absence and presence of 3PG for $3 \mathrm{~min}$ and subjected to SDS-PAGE and autoradiography. Actual counts incorporated: HTP + 3PG, $384 \mathrm{cpm} ; \mathrm{f}_{24}+3 P G, 76 \mathrm{cpm} ; \mathrm{f}_{24}+\mathrm{f}_{28}$ $+3 P G, 460 \mathrm{cpm} ; \mathrm{f}_{24}+\mathrm{T}+3 P \mathrm{PG}, 488 \mathrm{cpm}$; others are $<30 \mathrm{cpm}$.

followed by glucose-6-phosphate. Presumably, in each case, $\left[{ }^{32} \mathrm{P}\right] \mathrm{G} 1,6 \mathrm{P}_{2}$ was formed as a result of this removal. These effects were similar to those observed on dephosphorylation of $\mathrm{G} 1,6 \mathrm{P}_{2}$ synthetase (Rose et al., 1977). G1,6P and 1,3BPG also showed quite significant effects. The other compounds were much less effective.

Phosphopeptide mapping and phosphoamino acid analysis. To determine whether the site of phosphorylation of $3 \mathrm{PG}-\mathrm{PP}_{72}$ observed in the presence of $3 \mathrm{PG}$ and $\left[\gamma_{-}{ }^{32} \mathrm{P}\right] \mathrm{ATP}$ is the same as that observed with [1$\left.{ }^{32} \mathrm{P}\right] 1,3 \mathrm{BPG}, 3 \mathrm{PG}-\mathrm{PP}_{72}$ phosphorylated by both means was subjected to ${ }^{32} \mathrm{P}$-phosphopeptide and ${ }^{32} \mathrm{P}$-phosphoamino acid analyses. Phosphorylated $3 P G-P_{72}$ was digested with (a) trypsin/chymotrypsin, (b) thermolysin, and (c) Staphylococcus aureus V8 protease, and the digests were separated by high-voltage thin layer electrophoresis followed by chromatography. Peptide analysis indicates that the major ${ }^{32} \mathrm{P}$-phosphopeptide obtained with 3PG and $\left[\gamma^{32} \mathrm{P}\right] \mathrm{ATP}$ is indistinguishable from that obtained with $\left[1-{ }^{32} \mathrm{P}\right] 1,3 \mathrm{BPG}$, regardless of the type of proteolytic enzyme used (Fig. 5).

The trypsin/chymotrypsin digests were subjected to acid hydrolysis to determine the amino acid residues phosphorylated. As shown in Fig. 6, phosphorylation either with $\left[\gamma^{32}\right.$ P]ATP (in the presence of 3PG) or with $\left[1-{ }^{32} \mathrm{P}\right] 1,3 \mathrm{BPG}$ yielded $\left[{ }^{32} \mathrm{P}\right]$ phosphoserine. This, together with the data in Fig. 5, strongly suggests that the major site of phosphorylation of $3 \mathrm{PG}^{-} \mathrm{PP}_{72}$ with $\left[\gamma-{ }^{32} \mathrm{P}\right] \mathrm{ATP}$ and $3 \mathrm{PG}$ is identical to that phosphorylated with $\left[1-{ }^{32} \mathrm{P}\right] 1,3 \mathrm{BPG}$.

Stoichiometry of ${ }^{32} \mathrm{P}$ incorporated into $3 \mathrm{PG}-\mathrm{PP}_{72}$

After aliquots of the $3 \mathrm{PG}-\mathrm{PP}_{72}$ fractions from hydroxyapatite chromatography were incubated with $3 \mathrm{PG}$ and $\left[\gamma-{ }^{32} \mathrm{P}\right] \mathrm{ATP}$ or $\left[1-{ }^{32} \mathrm{P}\right] 1,3 \mathrm{BPG},{ }^{32} \mathrm{P}$ incorporation into $3 \mathrm{PG}-\mathrm{PP}_{72}$ was measured (Fig. 7 ). ${ }^{32} \mathrm{P}$ incorporation from $\left[\gamma-{ }^{32} \mathrm{P}\right] \mathrm{ATP}$ increased gradually to reach a maximal level at $10 \mathrm{~min}$, while ${ }^{32} \mathrm{P}$ was rapidly incorporated from $\left[1-{ }^{32} \mathrm{P}\right] 1,3 \mathrm{BPG}$, reaching a maximal level at $15 \mathrm{~s}$. The values of these maximal levels were 0.141 and $0.169 \mathrm{~mol}$ phosphate $/ \mathrm{mol} 3 \mathrm{PG}-\mathrm{PP}_{72}$, respectively. Our values are similar to those obtained for $\mathrm{G} 1,6 \mathrm{P}_{2}$ synthetase where the purified enzyme was reacted with $\left[1-{ }^{32} \mathrm{P}\right] 1,3 \mathrm{BPG}$ in the absence of glucose-1phosphate (which acts as an acceptor of the 1 -position phosphate from $1,3 \mathrm{BPG}$ ) to yield a value of 0.154 $0.231 \mathrm{~mol}$ phosphate/mol enzyme (Wong and Rose, 1976).

\section{Evidence for 1,3BPG as immediate donor of phosphate}

1,3BPG served as a phosphate donor for the phosphorylation of 3PG-PP 72 (Figs. 1, 2, and 7). Although $3 \mathrm{PG}-\mathrm{PP}_{72}$ was labeled with $\left[1-{ }^{32} \mathrm{P}\right] 1,3 \mathrm{BPG}$ in the $\mathrm{ab}-$ sence of ATP (Figs. 1, 2, and 7), it was not known whether 1,3BPG served as the immediate phosphate donor for the phosphorylation of $3 \mathrm{PG}-\mathrm{PP}_{72}$ that was observed with $3 \mathrm{PG}$ and $\left[\gamma_{-}{ }^{32} \mathrm{P}\right] \mathrm{ATP}$. To address this issue, three experiments were carried out. First, the effect of unlabeled $1,3 \mathrm{BPG}$ on the phosphorylation of

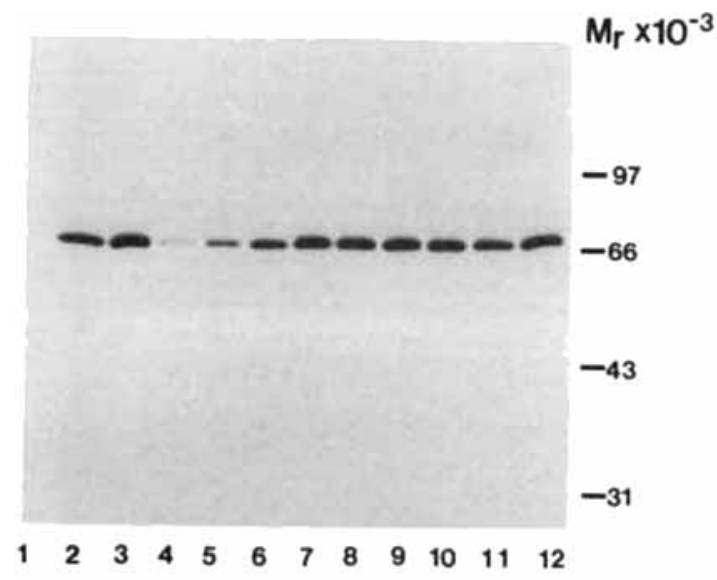

FIG. 4. Effect of glycolytic intermediates on dephosphorylation. The 3PG-PP 72 fraction from hydroxyapatite chromatography (containing $0.15 \mu \mathrm{g}$ of $3 \mathrm{PG} \mathrm{PP}_{72}, 17.0 \mu \mathrm{g}$ of total protein) was incubated with $\left[\gamma^{32}\right.$ P]ATP in the absence (lane 1) and presence (lane 2) of $3 P G$ for 5 min. After the incubation with $\left[\gamma-{ }^{32} P\right] A T P$ and $3 P G$ for $5 \mathrm{~min}$, various compounds $(1 \mathrm{mM})$ were added, and incubation was allowed to continue for an additional 2 min. Lane 3, water; lane 4, glucose-1-phosphate; lane 5, glucose-6-phosphate; lane 6, G1,6P ; lane 7, fructose-1-phosphate; lane 8 , fructose-6-phosphate; lane 9, fructose-1,6-bisphosphate; lane 10, fructose-2,6bisphosphate; lane 11, 1,3BPG; and lane 12, 2,3-bisphosphoglycerate. Samples were subjected to SDS-PAGE and autoradiography. Radioactivities associated with $3 P G-P_{72}$ in lanes $1-12$ were 12 , $1,483,1,970,312,636,1,134,1,718,1,736,1,747,1,577,1,319$, and $1,736 \mathrm{cpm}$, respectively. 

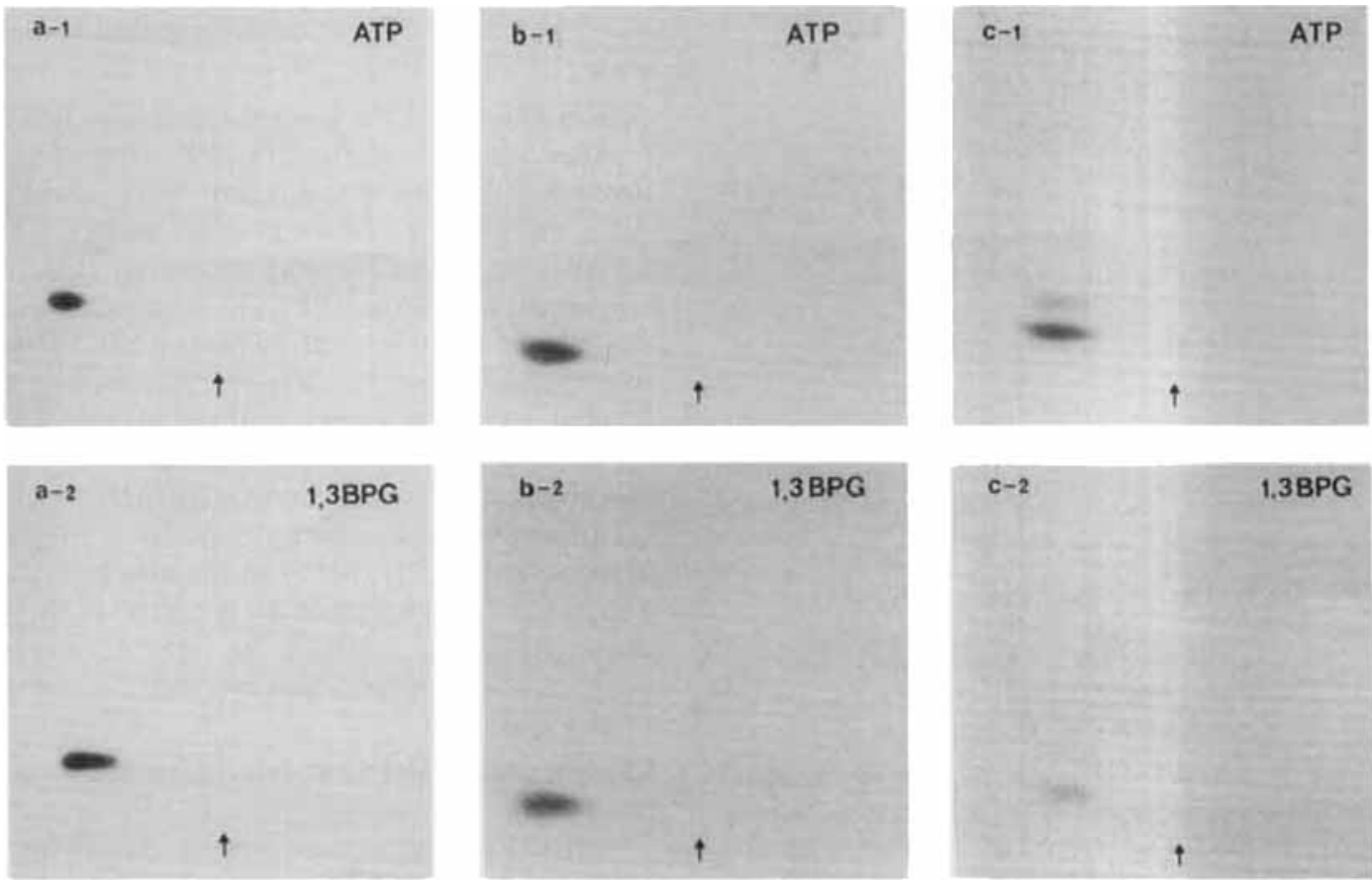

FIG. 5. Peptide mapping after limited proteolysis of phosphorylated 3PG-PP 72 . The 3PG-PP 72 fraction from Phenyl 5PW HPLC (containing $0.90 \mu \mathrm{g}$ of $\left.3 \mathrm{PG}-\mathrm{PP}{ }_{72}\right)$ was incubated with (1) $\left[\gamma^{32} \mathrm{P}\right] \mathrm{ATP}$ and $3 \mathrm{PG}$ or $(2)\left[1-{ }^{32} \mathrm{P}\right] 1,3 \mathrm{BPG}$ and subjected to SDS-PAGE and autoradiography. When the 3PG-PP 72 fraction was incubated with $\left[\gamma^{32} \mathrm{P}\right] \mathrm{ATP}$ and $3 \mathrm{PG}$, an aliquot of fraction 28 from Phenyl 5PW HPLC was added as a kinase source to the incubation mixture. The dry gel pieces containing $3 P G-P P_{72}$ were reswollen and digested at $37^{\circ} \mathrm{C}$ for $24 \mathrm{~h}$ with trypsin/ chymotrypsin (a-1, a-2), thermolysin (b-1, b-2), and Staphylococcus aureus V8 protease (c-1, c-2). The digests were separated first by electrophoresis in the horizontal dimension and then by ascending chromatography in the vertical dimension, as described in Materials and Methods. The origin of sample is indicated by arrows; the cathode is on the left and the anode on the right on each plate.
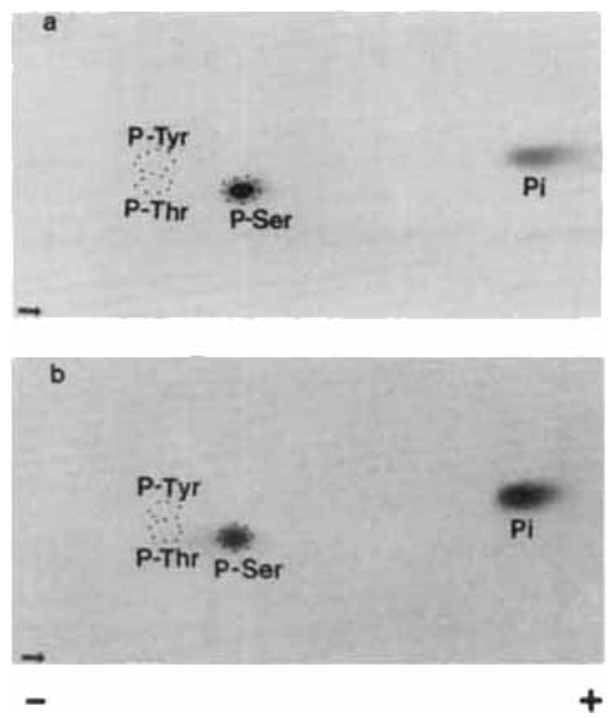

FIG. 6. Identification of the amino acids phosphorylated in 3PG$P P_{72}$. The 3PG-PP 72 fraction from Phenyl 5PW HPLC (containing $0.90 \mu \mathrm{g}$ of $\left.3 \mathrm{PG}-\mathrm{PP} \mathrm{P}_{72}\right)$ was incubated with $\left[\gamma^{32} \mathrm{P}\right] \mathrm{PTP}$ and $3 \mathrm{PG}(\mathrm{a})$ or $\left[{ }^{3}{ }^{32} \mathrm{P}\right] 1,3 \mathrm{BPG}(\mathrm{b})$ and subjected to SDS-PAGE and autoradiography. The trypsin/chymotrypsin digests of $\left[{ }^{32} \mathrm{P}\right] 3 \mathrm{PG}-\mathrm{PP}_{72}$ were prepared as described in Fig. 5 and subjected to partial acid hydrolysis. The hydrolysates were analyzed for phosphoamino acids by electrophoresis (in the horizontal dimension) and ascending chromatography (in the vertical dimension). The origin of sample is indicated by arrows.
3PG-PP 72 with $\left[y-{ }^{32} \mathrm{P}\right] \mathrm{ATP}$ and $3 \mathrm{PG}$ was examined. In data not shown, 1,3BPG effectively reduced the labeling of 3PG-PP $\mathrm{P}_{72} ; 50 \%$ inhibition was achieved at 10 $\mathrm{n} M$. Second, we determined the amount of $1,3 \mathrm{BPG}$ generated in a reaction mixture containing $\left[\gamma-{ }^{32} \mathrm{P}\right] \mathrm{ATP}$,

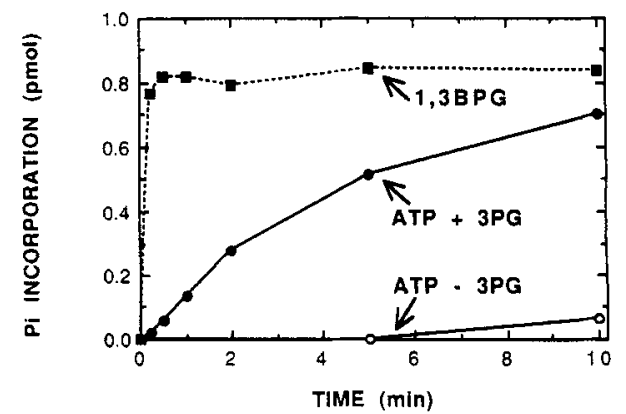

FIG. 7. Stoichiometry of ${ }^{32} \mathrm{P}$ incorporated into $3 P G-P P_{72}$. The 3PG$\mathrm{PP}_{72}$ fraction from hydroxyapatite chromatography (containing 0.35 $\mu \mathrm{g}$ of 3PG-PP $72,46 \mu \mathrm{g}$ of total protein) was incubated with $[\gamma-$ ${ }^{32} \mathrm{PJATP}$ in the presence (ATP + 3PG) and in the absence (ATP $3 P G)$ of $3 P G$. It was also incubated with $\left[1{ }^{32} P\right] 1,3 B P G(1,3 B P G)$. Samples were subjected to SDS-PAGE and autoradiography. The bands of $\left.{ }^{32} \mathrm{P}\right] 3 \mathrm{PG}-\mathrm{PP} \mathrm{P}_{72}$ were cut out and counted in a liquid scintillation spectrophotometer. The amount of $3 P G-P P_{72}$ was determined by densitometric tracing of protein bands stained by $\mathrm{CoO}$ massie Brilliant Blue R on slab SDS-PAGE, using bovine serum albumin as standard. 
3PG, 3PG-PP ${ }_{72}$, and our kinase fraction. A significant amount of radioactive $1,3 \mathrm{BPG}$ was indeed produced and the concentration of $1,3 \mathrm{BPG}$ was calculated to be $83 \mathrm{n} M$. Third, the effectiveness of radioactive 1,3BPG on phosphorylating $3 \mathrm{PG}-\mathrm{PP}_{72}$ was determined. Figure 8 shows that $3 \mathrm{PG}-\mathrm{PP} \mathrm{P}_{72}$ is almost fully phosphorylated with $83 \mathrm{n} M 1,3 \mathrm{BPG}$; the maximal phosphorylation was achieved at $100 \mathrm{n} M$, whereas the half-maximal phosphorylation was observed at $1.1 \mathrm{n} M$. All of these results support the argument that 1,3BPG serves as the immediate phosphate donor for the phosphorylation of $3 \mathrm{PG}-\mathrm{PP}{ }_{72}$ observed in the presence of $\left[\gamma_{-}{ }^{32} \mathrm{P}\right] \mathrm{ATP}$, 3PG, and 3PG kinase.

\section{Involvement of a distinct protein kinase in phosphorylation of $3 \mathbf{P G}-\mathbf{P P}_{\mathbf{1 5 5}}$}

We have previously reported that another protein in the synaptosomal cytosol, referred to as 3 PG-PP ${ }_{155}$, was also phosphorylated in the presence of $\left[\gamma_{-}{ }^{32} \mathrm{P}\right] \mathrm{ATP}$ and 3PG (Ueda and Plagens, 1987). To determine whether or not this phosphorylation involves $1,3 \mathrm{BPG}$, the synaptosomal cytosol fraction was incubated with [1-32 P]1,3BPG. As shown in Fig. 9, in contrast to the phosphorylation of $3 \mathrm{PG}-\mathrm{PP}_{72}$, the phosphorylation of 3PG-PP ${ }_{155}$ in the presence of $3 \mathrm{PG}$ and ATP was not mimicked by $\left[1-{ }^{32} \mathrm{P}\right] 1,3 \mathrm{BPG}$ (Fig. 9).

\section{DISCUSSION}

In this study, we have demonstrated that the 3PGdependent protein phosphorylation system for 3PG$\mathrm{PP}_{72}$ was resolved into two components, the substrate 3PG-PP ${ }_{72}$ and a kinase, which is likely to be 3 PG kinase catalyzing the formation of $1,3 \mathrm{BPG}$ from $3 \mathrm{PG}$ and ATP. Several lines of evidence indicate that $3 \mathrm{PG}-\mathrm{PP}_{72}$ is $G 1,6 P_{2}$ synthetase. These include (a) the identical chromatographic behavior we observed for both on hydroxyapatite and hydrophobic interaction chroma-

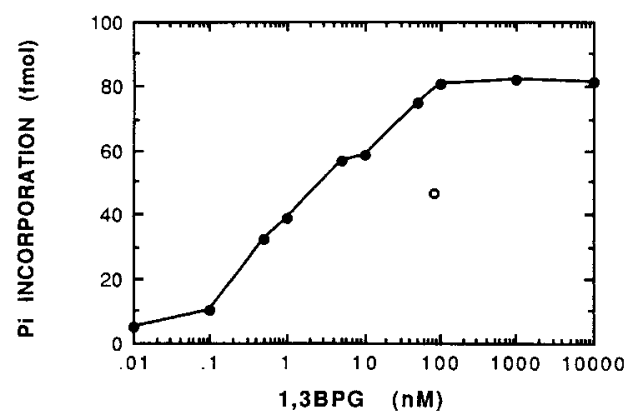

FIG. 8. Effect of various concentrations of $\left[1{ }^{32} \mathrm{P}\right] 1,3 \mathrm{BPG}$ on phosphorylation of $3 P P_{-}-P_{72}$. The 3PG-PP $P_{72}$ fraction from Phenyl 5PW HPLC (containing $0.14 \mu \mathrm{g}$ of $3 P G-P_{72}$ ) was incubated with various concentrations of $\left[1-{ }^{32} \mathrm{P}\right] 1,3 \mathrm{BPG}$ for $2 \mathrm{~min}(\bullet)$. Samples were subjected to SDS-PAGE and autoradiography. The gel pieces containing $3 \mathrm{PG}-\mathrm{PP}_{72}$ were cut out, using the autoradiogram as a guide, and the amount of ${ }^{32} P_{1}$ incorporated was determined in a liquid scintillation spectrophotometer. The 3PG-PP 72 fraction from Phenyl 5PW HPLC was also incubated with $20 \mu M\left[\gamma^{32}\right.$ P]ATP and $5 \mathrm{mM} 3 \mathrm{PG}$ in the presence of the major kinase fraction [fraction $28,37-\mu \mathrm{l}$ aliquot $(O)]$

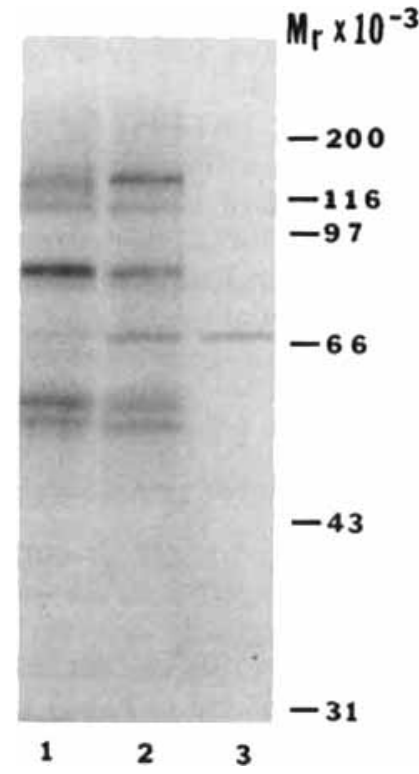

FIG. 9. Protein phosphorylation pattern of synaptosomal cytosol produced with $\left[1{ }^{32} \mathrm{P}\right] 1,3 \mathrm{BPG}$ in comparison with that observed with $\left[\gamma^{32}\right.$ P]ATP plus 3PG. Aliquots of the synaptosomal cytosol fraction ( $25 \mu \mathrm{g}$ of protein) that had been dialyzed for $18 \mathrm{~h}$ against $10 \mathrm{mM}$ Tris-HCl buffer ( $\mathrm{pH} 7.4)$ were phosphorylated with $20 \mu M$ [ $\gamma{ }^{32}$ P]ATP $(16.5 \mathrm{Ci} / \mathrm{mmol})$ for $2 \mathrm{~min}$ in the absence (lane 1$)$ and presence (lane 2) of $5 \mathrm{mM}$ 3PG or with $10 \mu M\left[1{ }^{32} \mathrm{P}\right] 1,3 \mathrm{BPG}$ (10.6 $\mathrm{Ci} / \mathrm{mmol}$; lane 3) in the absence of 3PG. The phosphorylated samples were then subjected to SDS-PAGE and autoradiography.

tographies, (b) the ability of $1,3 \mathrm{BPG}$ to serve as the direct phosphate donor for the phosphorylation of both, (c) the identical amino acid phosphorylated by 1,3BPG or by ATP and 3PG in the presence of 3PG-dependent kinase, (d) highly similar phosphopeptide fragments generated with proteolytic enzymes, (e) highly similar molecular weights in SDS, and (f) the abundant occurrence of both in the mammalian brain. Thus, it is likely that the phosphorylation of $3 \mathrm{PG}-\mathrm{PP}_{72}$ with $[\gamma$ $\left.{ }^{32} \mathrm{P}\right] \mathrm{ATP}$ observed in the presence of $3 \mathrm{PG}$ in the synaptosomal cytosol fraction represents the phosphoryl transfer to 3 PG-PP 72 from the acyl phosphate of $1,3 \mathrm{BPG}$, which is generated from $3 \mathrm{PG}$ and $\mathrm{ATP}$, perhaps by 3 PG kinase present in the preparation.

In both our study and that of Rose et al. (1977), the value calculated for the amount of ${ }^{32} \mathrm{P}$ incorporated into $\mathrm{G} 1,6 \mathrm{P}_{2}$ synthetase is too low if the enzyme is homogeneous. However, it is likely that the homogeneous protein may contain either an inactive or a phosphorylated form of the enzyme.

It is known that $1,3 \mathrm{BPG}$ serves as a phosphoryl donor not only to $\mathrm{G} 1,6 \mathrm{P}_{2}$ synthetase (Rose et al., 1975) but also to 2,3-bisphosphoglycerate synthetase-phosphatase (Rose and Whalen, 1973). Whereas 1,3BPG phosphorylates a serine residue of $\mathrm{Gl}, 6 \mathrm{P}_{2}$ synthetase (Wong and Rose, 1976), it phosphorylates a histidine residue on 2,3-bisphosphoglycerate synthetase-phosphatase (Rose and Whalen, 1973). G1,6 $\mathrm{P}_{2}$ synthetase has a molecular weight of 72,000 and is a monomer (Wong and Rose, 1976), while the subunit of 2,3-bis- 
phosphoglycerate synthetase-phosphatase has a molecular weight of 30,000 in SDS-PAGE and is a dimer (Rose and Whalen, 1973).

The apparent $K_{\mathrm{m}}$ of $3 \mathrm{PG}-\mathrm{PP}_{72}$ for $1,3 \mathrm{BPG}$ in the phosphorylation reaction (Eq. 1) is $1.1 \mathrm{nM}$. On the other hand, a $K_{\mathrm{m}}$ value of $0.07 \mu M$ was reported by Wong and Rose (1976) for G1,6 $\mathrm{P}_{2}$ synthetase, as measured in the overall synthetase reaction in the presence of an infinite amount of glucose-1-phosphate, i.e., the rate of $\mathrm{Gl}, 6 \mathrm{P}_{2}$ formation (Eqs. 1 and 2):

$$
\begin{aligned}
1,3 \mathrm{BPG}+\mathrm{E} & \rightarrow \mathrm{E}-\mathrm{P}+3 \mathrm{PG} \\
\mathrm{E}-\mathrm{P}+\text { glucose- } 1-\mathrm{P} & \rightarrow \mathrm{G} 1,6 \mathrm{P}_{2}+\mathrm{E}
\end{aligned}
$$

The low apparent $K_{\mathrm{m}}, 1.1 \mathrm{n} M$ or $0.07 \mu M$, of the G1,6 $\mathrm{P}_{2}$ synthetase for $1,3 \mathrm{BPG}$ in the formation of $\mathrm{E}$ $P$ may reflect physiologically relevant levels of the 1,3BPG. The levels of 1,3BPG in the brain and erythrocytes have been estimated to be $<1 \mu M$ (Lowry et al., 1964) and 0.39-0.7 $\mu M$ (Minakami and Yoshikawa, 1965), respectively.

G1, $6 P_{2}$, the product of the $G 1,6 P_{2}$ synthetase reaction, is a phosphate donor to a family of enzymes that participate in unique sugar phosphate mutase reactions, such as those not only for glucose phosphate but also for ribose phosphate, mannose phosphate, and acetylglucosamine phosphate (Rose, 1986). G1,6 $\mathrm{P}_{2}$ can also act as a regulator of some of the key enzymes in carbohydrate metabolism. It has been shown to activate phosphoglucomutase, phosphofructokinase, and pyruvate kinase and to inhibit hexokinase, 6-phosphogluconate dehydrogenase, and fructose-1,6-diphosphatase (Beitner, 1985). Since 1,3BPG is the phosphate donor for the formation of $\mathrm{G} 1,6 \mathrm{P}_{2}, 1,3 \mathrm{BPG}$ could serve as a feed-forward regulator in glycolysis.

The regional distribution of $G 1,6 P_{2}$ synthetase in the brain coincides with that of G1,6 $\mathrm{P}_{2}$ and IMP-dependent $\mathrm{G} 1,6 \mathrm{P}_{2}$ phosphatase (Yip et al., 1985). However, it does not parallel the distribution of phosphoglucomutase, and $\mathrm{G} 1,6 \mathrm{P}_{2}$ levels are much higher than the concentration required for the cofactor role in the phosphoglucomutase reaction (Yip et al., 1988). In addition, the $\mathrm{G} 1,6 \mathrm{P}_{2}$ system failed to exhibit a regional correlation with other enzymes involved in carbohydrate metabolism and with glucose consumption (Sokoloff et al., 1977). Moreover, 3PG-PP 72 , now identified as $\mathrm{Gl}, 6 \mathrm{P}_{2}$ synthetase, has been shown to be present in the brain at much higher concentrations than in "nonnervous tissues" such as liver, kidney, lung, and heart (Ueda and Plagens, 1987). Based upon these observations, the possibility is raised that $\mathrm{G} 1,6 \mathrm{P}_{2}$ may fill some other function besides serving as the cofactor for sugar phosphate mutase. For example, it may serve as a phosphate donor for a neuronal protein and thereby play a role in synaptic function. The results presented here and by Rose et al. (1975) suggest that $\mathrm{G} 1,6 \mathrm{P}_{2}$ production is facilitated through an increase in the formation of the active phosphorylated intermediate of $\mathrm{G} 1,6 \mathrm{P}_{2}$ synthetase by the glycolytic intermediate 1,3BPG. Thus, it is conceivable that glycolysis could play a role in synaptic function via 1,3BPG and G1,6 $P_{2}$ followed by $\mathrm{G} 1,6 \mathrm{P}_{2}$-supported phosphorylation of a synaptic protein.

In contrast to the phosphorylation system for 3PG$\mathrm{PP}_{72}$, where the $72-\mathrm{kDa}$ protein is phosphorylated by either ATP and 3PG or 1,3BPG, the 155-kDa protein is phosphorylated by ATP and 3PG, but not by 1,3BPG. Direct transfer of phosphate from ATP to the protein substrate rather than via the intermediate $1,3 \mathrm{BPG}$ formation remains a viable possibility and is compatible with the notion that a 3PG-dependent protein kinase is responsible for the phosphorylation of the $155-\mathrm{kDa}$ protein. Thus, the $155-\mathrm{kDa}$ protein is phosphorylated in a manner different than is $3 \mathrm{PG}-\mathrm{PP}_{72}$. This notion is also supported by the previous observation that, unlike the phosphorylation of $3 \mathrm{PG} \mathrm{PP}_{72}$, the phosphorylation of $3 \mathrm{PG}-\mathrm{PP}{ }_{155}$ with $\left[\gamma^{32} \mathrm{P}\right] \mathrm{ATP}$ was stimulated not only by 3 PG but also by unlabeled 2 phosphoglycerate or 2,3-bisphosphoglycerate (Ueda and Plagens, 1987).

Acknowledgment: This work was supported by NIH grant NS24384. The authors wish to thank Douglas Plagens for his technical assistance in some of the initial experiments.

\section{REFERENCES}

Beitner R., ed. (1985) Regulation of Carbohydrate Metabolism, Vol. 1: Glucose-1,6-Bisphosphate-The Regulator of Carbohydrate Metabolism, pp. 1-27. CRC Press, Boca Raton.

Cox D. W. G. and Bachelard H. S. (1982) Attenuation of evoked field potentials from dentate granule cells by low glucose, pyruvate, malate, and sodium fluoride. Brain Res. 239, 527-534.

Dirks B., Hanke H., Krieglstein J., Stock R., and Wickop G. (1980) Studies on the linkage of energy metabolism and activity in the isolated perfused rat brain. J. Neurochem. 35, 311-317.

Ghajar J. B. G., Plum F., and Duffy T. E. (1982) Cerebral oxidative metabolism and blood flow during acute hypoglycemia and recovery in unanesthetized rats. $J$. Neurochem. 38, 397-409.

Huttner W. B. and Greengard P. (1979) Multiple phosphorylation sites in protein 1 and their differential regulation by cyclic AMP and calcium. Proc. Natl. Acad. Sci. USA 76, 5402-5406.

Lowry O. H., Rosebrough N. J., Farr A. L., and Randall R. J. (1951) Protein measurement with the Folin phenol reagent. J. Biol. Chem. 193, 265-275.

Lowry O. H., Passonneau J. V., Hasselberger F. X., and Schultz D. W. (1964) Effect of ischemia on known substrates and cofactors of the glycolytic pathway in the brain. J. Biol. Chem. $239,18-30$.

Minakami S. and Yoshikawa H. (1965) Thermodynamic considerations on erythrocyte glycolysis. Biochem. Biophys. Res. Commun. 18, 345-349.

Negelein E. (1957) Synthesis, determination, analysis and properties of 1,3-diphosphoglyceric acid, in Methods in Enzymology, Vol. 3 (Colowick S. P. and Kaplan N. O., eds), pp. 216-220. Academic Press, New York.

Nestler E. J. and Greengard P. (1984) Protein Phosphorylation in the Nervous System. John Wiley \& Sons, New York.

Rose I. A., Warms J. V. B., and Kaklij G. (1975) A specific enzyme for glucose 1,6-bisphosphate synthesis. J. Biol. Chem. 250, 34663470 .

Rose I. A., Warms J. V. B., and Wong L. J. (1977) Inhibitors of glucose-1,6-bisphosphate synthetase. J. Biol. Chem. 252, 42624268 .

Rose Z. B. (1968) The purification and properties of diphosphoglycerate mutase from human erythrocytes. J. Biol. Chem. 243, $4810-4820$. 
Rose Z. B. (1986) The glucose bisphosphate family of enzymes. Trends Biol. Sci. 7, 253-255.

Rose Z. B. and Whalen R. G. (1973) The phosphorylation of diphosphoglycerate mutase. J. Biol. Chem. 248, 1513-1519.

Scopes R. K. (1975) 3-Phosphoglycerate kinase of skeletal muscle, in Methods in Enzymology, Vol. 42 (Woods W. A., ed), pp. 127134. Academic Press, New York.

Siesjö B. K. (1978) Brain Energy Metabolism, pp. 101-130. John Wiley \& Sons, New York.

Sokoloff L., Reivich M., Kennedy M., des Rosiers M. H., Patlak C. S., Pettigrew K. D., Sakurada O., and Shinohara M. (1977) The $\left[{ }^{14} \mathrm{C}\right]$ deoxyglucose method for the measurement of local cerebral glucose utilization: theory, procedure, and normal values in the conscious and anesthetized albino rat. J. Neurochem. 28 , 897-916.

Stratford C. A., Fisher S. K., and Ueda T. (1984) Ergopeptine-sensitive calcium-dependent protein phosphorylation system in the brain. J. Neurochem. 42, 842-855.

Ueda T. and Greengard P. (1977) Adenosine $3^{\prime}: 5^{\prime}$-monophosphateregulated phosphoprotein system of neuronal membranes. I. Solubilization, purification, and some properties of an endogenous phosphoprotein. J. Biol. Chem. 252, 5155-5156.
Ueda T. and Plagens D. G. (1987) 3-Phosphoglycerate-dependent protein phosphorylation. Proc. Natl. Acad. Sci. USA 84, 12291233.

Ueda T., Maeno H., and Greengard P. (1973) Regulation of endogenous phosphorylation of specific proteins in synaptic membrane fractions from rat brain by adenosine $3^{\prime}: 5^{\prime}$ monophosphate. $J$. Biol. Chem. 248, 8295-8305.

Ueda T., Greengard P., Berzins K., Cohen R. S., Blomberg F., Grab D. J., and Siekevitz P. (1979) Subcellular distribution in cerebral cortex of two proteins phosphorylated by a cAMP-dependent protein kinase. J. Cell Biol. 83, 308-319.

Winkler B. S. (1981) Glycolytic and oxidative metabolism in relation to retinal function. J. Gen. Physiol. 77, 667-692.

Wong L. J. and Rose I. (1976) Kinetic competence of a phosphoryl enzyme intermediate in the glucose- $1,6-\mathrm{P}_{2}$ synthase-catalyzed reaction. J. Biol. Chem. 251, 5431-5439.

Yip V., Carter J. G., Dick E., Rose Z. B., and Lowry O. H. (1985) Distribution of glucose-1,6-bisphosphate and IMP-activated glucose bisphosphatase in brain and retina. J. Neurochem. 44, $1741-1746$.

Yip V., Pusateri M. E., Carter J., Rose I. A., and Lowry O. H. (1988) Distribution of the glucose-1,6-bisphosphate system in brain and retina. $J$. Neurochem. 50, 594-602. 